\title{
ECOLOGICAL AND SEXUAL VARIATION IN DROSOPHILA RUBIDA INVERSION POLYMORPHISM
}

WHARTON B. MATHER *

Department of Zoology, University of Queensland, Brisbane

\section{INTRODUCTION}

Received $18 . i x .62$

The species Drosophila rubida extends from northern Queensland throughout Papua and New Guinea, is rich in inversion polymorphism and shows marked geographical variation in inversion frequencies (Mather, $196 \mathrm{r}$, 1962). The purpose of this investigation is to determine whether there is inversion frequency variation between two ecological niches within the same general geographical region and whether the inversion frequency of the sexes is different. The former type of experiment has only been reported with Drosophila pseudoobscura (Dobzhansky, 1947) and the latter with Drosophila robusta (Levitan, 195I). Both these species are temperate north American species and it is therefore of interest to carry out both experiments in a tropical species.

\section{THE EXPERIMENTS}

The two stations chosen for the experiment are situated at Brown River and Bisianumu some 20 and 25 miles respectively from Port Moresby, Territory of Papua and New Guinea. The Brown River station is in thick rain forest and at sea level whereas the Bisianumu station is in a rubber plantation at 1500 feet but with some adjacent secondary rain forest. The direct distance between the two stations is 20 miles. At each station four separate baits of $2-3 \mathrm{lb}$. of fermenting banana were placed in shady situations and the Drosophila attracted thereto sampled during the next two days. D. rubida individuals were subsequently mated to a standard inversion free strain after the females had been despermed and the salivary glands of seven larvæ from each mating examined to ensure an over 98 per cent. probability of sampling both chromosome sets of each fly. In all, 158 flies were tested and I ro6 slides scored. The flies were collected in February 1962. Further details of the methods used may be found in Mather (196r).

TABLE I

Chromosome II inversion frequencies

\begin{tabular}{|c|c|c|c|c|c|c|c|}
\hline & \multirow{2}{*}{$\begin{array}{l}\text { Brown } \\
\text { River } \\
\text { male } \\
\text { per cent. }\end{array}$} & \multirow{2}{*}{$\begin{array}{c}\text { Brown } \\
\text { River } \\
\text { female } \\
\text { per cent. }\end{array}$} & \multirow{2}{*}{$\begin{array}{c}\text { Bisianumu } \\
\text { male } \\
\text { per cent. }\end{array}$} & \multicolumn{2}{|c|}{ Brown River } & \multicolumn{2}{|c|}{ Males } \\
\hline & & & & $\underset{\mathrm{X}^{2}}{\text { male }}$ & $\underset{P}{\text { female }}$ & $\begin{array}{c}\text { Brown } \\
\text { River } \\
X^{2}\end{array}$ & $\underset{P}{\text { Bisianumu }}$ \\
\hline Standard & $66 \cdot 5$ & $33 \cdot 3$ & $36 \cdot 9$ & $16 \cdot 64$ & $<0.001$ & $20 \cdot 78$ & $<0.001$ \\
\hline IILA & 0.5 & $2 \cdot 2$ & $2 \cdot 4$ & 0.04 & $>0.05$ & 0.52 & $>0.05$ \\
\hline IIRA & 0.5 & $2 \cdot 2$ & $7 \cdot 1$ & 0.04 & $>0.05$ & $7 \cdot 66$ & $<0.01$ \\
\hline & $2 \cdot 1$ & $I I \cdot I$ & 16.7 & $7 \cdot 25$ & $<0.01$ & $20 \cdot 01$ & $<0.001$ \\
\hline & $20 \cdot 7$ & $3^{1} \cdot \mathrm{I}$ & $29 \cdot 8$ & $2 \cdot 22$ & $>0.05$ & $2 \cdot 62$ & $>0.05$ \\
\hline & $12 \cdot 2$ & 33.3 & $3^{2 \cdot 1}$ & ${ }^{1} 3 \cdot 65$ & $<0.001$ & $17.5^{8}$ & $<0.001$ \\
\hline No. of flies & 94 & 22 & $4^{2}$ & & & & \\
\hline
\end{tabular}

* Aided by a grant from the University of Queensland Research Fund. 


\section{RESULTS}

The results are set out in tables $I$ and 2. Inversions IIRD and IIIF are complex. Inversion IIRD contains four simple inversions and IIIF two simple inversions. The other inversions are simple. From the tables it will

TABLE 2

Chromosome III inversion frequencies

\begin{tabular}{|c|c|c|c|c|c|c|c|c|}
\hline & \multirow{2}{*}{$\begin{array}{c}\text { Brown } \\
\text { River } \\
\text { male } \\
\text { per cent. }\end{array}$} & \multirow{2}{*}{$\begin{array}{c}\text { Brown } \\
\text { River } \\
\text { female } \\
\text { per cent. }\end{array}$} & \multirow{2}{*}{$\begin{array}{c}\text { Bisianumu } \\
\text { male } \\
\text { per cent. }\end{array}$} & \multicolumn{2}{|c|}{ Brown River } & \multicolumn{2}{|c|}{ Males } \\
\hline & & & & & $\underset{\mathrm{X}^{2}}{\operatorname{male}}$ & $\underset{\mathbf{P}}{\text { female }}$ & $\begin{array}{c}\text { Brown } \\
\text { River } \\
\mathrm{X}^{2}\end{array}$ & $\begin{array}{c}\text { Bisianumu } \\
\mathbf{P}\end{array}$ \\
\hline \multicolumn{2}{|c|}{ Standard } & $68 \cdot 6$ & $66 \cdot 7$ & $83 \cdot 3$ & 0.06 & $>0.05$ & $6 \cdot 40$ & $<0.05$ \\
\hline A & . & $4 \cdot 8$ & 0.0 & $2 \cdot 4$ & 0.16 & $>0.05$ & $0 \cdot 36$ & $>0.05$ \\
\hline B & . & $5 \cdot 3$ & $2 \cdot 2$ & $1 \cdot 2$ & 0.23 & $>0.05$ & $1 \cdot 60$ & $>0.05$ \\
\hline G & . & $3 \cdot 7$ & $0 \cdot 0$ & $2 \cdot 4$ & 0.00 & $>0.05$ & 0.04 & $>0.05$ \\
\hline D & . & $3 \cdot 7$ & $2 \cdot 2$ & $3 \cdot 6$ & 0.00 & $>0.05$ & 0.40 & $>0.05$ \\
\hline E & . & $21 \cdot 3$ & $3 I \cdot I$ & $8 \cdot 3$ & $2 \cdot 07$ & $>0.05$ & $5 \cdot 93$ & $<0.05$ \\
\hline $\mathbf{F}$ & . $\quad$. & $I \cdot 6$ & $2 \cdot 2$ & $3 \cdot 6$ & $2 \cdot 15$ & $>0.05$ & $2 \cdot 18$ & $>0.05$ \\
\hline \multicolumn{2}{|c|}{ No. of flies } & 94 & 22 & $4^{2}$ & & & & \\
\hline
\end{tabular}

be seen that at Brown River there are significant differences between the sexes in the frequencies of 3 of the 13 gene sequences present in chromosomes II and III. Furthermore there are significant differences in the frequencies of 6 of the 13 gene sequences present in chromosomes II and III between males at Brown River and Bisianumu.

\section{DISCUSSION}

The differences in gene sequence frequencies between males and females reported here remind one of the situation reported by Levitan (I95I) for D. robusta. He found that chromosomal type $2 \mathrm{~L}$ was present to the extent of $44^{\circ} 9$ per cent. in males and $25^{\circ} 0$ per cent. in females in a spring population. In a fall population the figures were altered to 34.3 per cent. in males and $50 \cdot 0$ per cent. in females but there was still a significant difference between the sexes.

The different gene sequence frequencies between males at Brown River and Bisianumu parallel the case described by Dobzhansky (1947) for $D$. pseudoobscura where three populations only 10-15 miles apart on Mount San Jacinto in Southern California showed marked differences. At the three stations, Keen Camp, Pinon Flats, and Andreas Canyon, the frequencies of the St and Ch gene arrangements were $33^{\circ} 7,40^{\circ} 7$ and $57^{\circ} 6$ and $35^{\circ} 0,29^{\circ}$ I and 15.3 respectively.

The maintenance of heterozygosity of gene sequences in a population has been satisfactorily explained in a number of species of Drosophila, including $D$. pseudoobscura and $D$. robusta, by the superiority of the heterozygotes, and geographical variation in the gene sequence frequencies by different fitness values in different environments. The interest of the $D$. rubida case is that at the same time gene sequence frequencies and presumably fitness values can be so different at stations so close together. 
The clear difference in the gene sequence frequencies between sexes in the one population would suggest the possibility that for a given set of conditions as many as three equilibrium points for a gene sequence frequency may be possible, for Owen (1953) has demonstrated theoretically that provided the males and females in a population have genotypes with fitness values that differ in direction and degree two stable equilibria are possible and there is one unstable equilibrium between them.

\section{SUMMARY}

I. Six out of thirteen gene sequences of $D$. rubida show significant differences of frequencies at two stations only 20 miles apart in New Guinea.

2. Three out of thirteen gene sequences show significant differences of gene sequences between sexes at the one station.

3. Attention is drawn to the possibility that in the population showing significant differences of gene frequency between sexes as many as three equilibrium frequencies may be possible for a particular set of environmental conditions.

Acknowledgments.-Acknowledgments are owing to Miss R. Spurway, Miss R. Harlock and Mr. F. M. Khan for technical assistance.

\section{REFERENCES}

DOBZhaNsKy, T. 1947. A directional change in the genetic constitution of a natural population of Drosophila pseudoobscura. Heredity, 1, 53-64.

LEVITAN, M. 1951. Experiments on chromosomal variability in Drosophila robusta. Genetics, $36,285-305$.

oWEN, A. R. G. 1953. A genetical system admitting of two distinct stable equilibria under natural selection. Heredity, 7, 97-102.

mather, W. B. I961. Chromosomal polymorphism in Drosophila rubida Mather. Genetics, 46, 799-810.

mather, w. B. 1962. Patterns of chromosomal polymorphism in Drosophila rubida. American Naturalist (in press). 